\title{
Kecenderungan Gaya Belajar Mahasiswa dalam Mengikuti Implementasi Penugasan Dosen Sekolah
}

\author{
Adi Sumarsono ${ }^{1}$, Nyoman Widiantari ${ }^{2}$, Etriana Meirista ${ }^{3}$ \\ Jurusan Pendidikan Jasmani Kesehatan dan Rekreasi, Universitas Musamus ${ }^{1}$ \\ Lembaga Penelitian dan Pengabdian Univesitas Negeri Gorontalo ${ }^{2}$ \\ Jurusan Pendidikan Matematika, Universitas Musamus ${ }^{3}$ \\ Emile: adi@unmus.ac.id ${ }^{1}$,widiantarikimia2011@gmail.com², etriana@unmus.ac.id ${ }^{2}$
}

\begin{abstract}
Abstrak
Proses perkuliahan dapat tercapai sesuai arahan kurikulum jika interaksi antara ilmu yang diberikan dan respon penerima dapat terjadi nyata secara linier. Tujuan dari penelitian ini adalah mendeskripsikan kecenderungan gaya belajar mahasiswa saat mengikuti perkuliahan pada program Penugasan dosen Sekolah (PDS) pada mata kuliah kepalatihan dasar. Metode yang digunakan dalam penelitian ini adalah deskriptif kuantitatif. Subyek yang dilibatkan dari penelitian ini sebanyak dua kelas yang terdiri dari masing-masing kelas sebanyak 32 mahasiswa. Instrumen yang digunakan dalam penelitian ini adalah angket skala belajar, wawancara dan dokumentasi. Aspek yang hendak diukur dalam penelitian ini meliputi tiga aspek yaitu, gaya belajar visual, gaya belajar auditori dan gaya belajar kinestetik. Hasil penelitian ini adalah terdapat kecenderugan gaya belajar mahasiswa di jurusan pendidikan jasmani kesehatan dan rekreasi dalam mengikuti perkuliahan Implementasi PDS. Adapun hasil dari penelitian ini dapat dijelaskan bahwa gaya belajar visual sebesar $38,30 \%$, sedangkan gaya belajar auditori sebesar $53,55 \%$ dan juga gaya belajar kinestetik mahasiswa sebesar 96,30\%. Dari hasil penelitian ini dapat disimpulkan bahwa mahasiswa pada jurusan PJKR UNMUS lebih cenderung suka dan mudah dalam memahami jika materi yang disampaikan dalm bentuk di keterampilan yang langsung dipraktekkan dari pada menggunakan gaya belajar yang mempunyai kecenderungan selain kinestetik.
\end{abstract}

Kata Kunci:Gaya Belajar, Mahasiswa PJKR

\section{Tendensi of Student Learning Styles in Attending the Implementation of School Lecturer Assignments}

Abstract

The lecture process can be achieved according to curriculum direction if the interaction between the given knowledge and the recipient's response can occur linearly. The purpose of this study is to describe the tendency of student learning styles when attending lectures in the School Lecturer Assignment (PDS) program in basic course subjects. The method used in this research is quantitative descriptive. Subjects involved in this study were as many as two classes consisting of each class of 32 students. The instruments used in this study were study scale questionnaires, interviews and documentation. The aspects to be measured in this study include three aspects namely, visual learning style, auditory learning style and kinesthetic learning style. The results of this study are there are trends in student learning styles in the physical health and recreation education majors in attending PDS Implementation lectures. The results of this study can be explained that the visual learning style is $38.30 \%$, while the auditory learning style is $53.55 \%$ and also the kinesthetic learning style is $96.30 \%$. From the results of this study it can be concluded that students in the UNMUS PJKR majors are more likely to like and easily understand if the material delivered preformance in the form of skills that are directly practiced rather than using learning styles that have trends other than kinesthetic.

Kata Kunci: Learning Style, PJKR Students 


\section{PENDAHULUAN}

Kemandirian mahasiswa sangat dituntut dalam dunia perkuliahan. Masing-masing mahasiswa diberikan kebebasan dalam mencari, mereduksi dan menyimpulkan analisis kejadian dalam memahami sesuatu didukung oleh teori yang sudah baku. Untuk itulah setiap mahasiwa mempunyai gaya belajar yang berbeda dalam mengikuti perkuliahan. Patokan hasil yang diharapkan bukan hanya nilai yang tinggi akan tetapi tersimpannya memori pemahaman tentang materi kuliah dalam tingkat pemahaman.

Jurusan pendidikan Jasmani Kesehatan dan Rekreasi (PJKR) adalah salah satu jurusan yang berada di bawah naungan Fakultas Keguruan dan Ilmu Pendidikan (FKIP) di Universitas Musamus. Jumlah mahasiswa jurusan PJKR setiap tahunnya beragam dan meningkat. Berdasarkan jenis mahasiswa yang mendafatr dan sudah kuliah terdiri dari putra asli Papua maupun dari mahasiwa pendatang. Berdasarkan kurikulum PJKR bertujuan menciptakan calon guru pendidikan jasmani, maka setiap mahasiswa diberikan materi kuliah yang berbentuk teori dan juga sekaligus praktek. Mahasiswa menempuh proses perkuliahan, diwajibkan bukan hanya mengikuti perkuliahan akan tetapi juga meningkatkan pemahaman dari dasar teori yang menjadi rujukan materi perkuliahan.

Proses perkuliahan yang dilaksanakan sesuai dengan kesepakatan, setiap mahasiwa melakukan proses pembelajaran dengan kecenderungan yang berbeda-beda. Dalam perkuliahan yang dijelaskan oleh dosen baik yang dilakukan teori didalam kelas maupun praktek dilapangan. Berdasarkan motivasi mahasiswa dalam menempuh perkuliahan di Jurusan Pendidikan Jasmani Kesehatan dan Rekreasi sangat beragam. Keberagaman dalam motivasi mahasiswa tersebut mempengaruhi daya belajar serta hasil belajar. Selain dari daya belajar dan motivasi belajar masih ada satu lagi yaitu gaya belajar mahasiswa. Berdasarkan hasil pengamatan dan observasi wawancara kepada mahasiswa pada jurusan PJKR UNMUS pada saat impelementasi program implementasi PDS, didapatkan fakta bahwa motivasi tertinggi masuk pada jurusan pendidikan jasmani adalah untuk menjadi jembatan dalam mendapatkan profesi guru pendidikan jasmani. Gaya belajar setiap mahasiswa juga mempengaruhi pretasi dan semangat belajar mahasiswa.

Permasalahan yang muncu dari tujuan penelitian ini adalah hasil impelementasi pembelajaran PDS pada mahahsiswa jurusan pendidikan jasmani kesehatan dan rekreasi, didapatkan informasi bahwa hasil belajar mahasiswa selama mengikuti perkuliahan masih terkendala dengan informasi perkuliahan. Hasil belajar mahasiswa selama mengikuti perkuliahan yang menggunakan media belajar daring menggambarkan hasil bahwa masih ditemukan sebagaian besar mahahsiswa terkendala dengan media kuliah. Dasar dari kendala mahasiswa tersebut diidentifikasi dari gaya belajarnya. Penelitian 
ini selanjutnya mengidentifikasi

kecenderungan mahasiswa dalam mengikuti perkuliahan dengan menggunakan gaya belajar berjenis dapa dan bagaimana mengatasi dari permaslahan tersebut.

Berdasarkan pengertiannya, gaya belajar merupakan ciri khas setiap individu dalam mengikuti proses pembelajaran. Gaya belajar merupakan suatu proses gerak laku, penghayatan, serta kecenderaungan seseorang pelajar mempelajari atau memperoleh suatu ilmu dengan cara tersendiri (Susilo, 2006). Senada dengan itu gaya belajar merupakan cara belajar yang khas bagi siswa (Winkel, 2005). Gaya belajar dalam memnuhi proses pembelajaran yang beragam mengakibatkan dalam prosesnya selalu mengalami karakteristik pembelajaran yang berbeda pula. Seseorang yang sudah mengalami proses dapat menyerap materi sesuai dengan ciri khas masing-masing. Gaya belajar merupakan suatu kombinasi dari bagaimana seseorang menyerap, mengatur dan selanjutnya mengolah informasi (De Porter, 2010).

Karena gaya belajar setiap orangnya yang berbeda (J. Philip, C.B. Rao, T. Jayakumar, B. Raj, 2000), maka untuk mencapai level prestasi belajar wajib melakukan mengetahui ciri khas masing-masing individu untuk melakukan tugas penyesauain dalam belajar. Jika bisa memahami bagaimana perbedaan gaya belajar setiap orang, mungkin akan mudah jika suatu ketika memandunya untuk mendapatkan gaya belajar yang tepat sesuai dengan karakteristik individu (Uno, 2004).

Oleh karena itu baik si pemberi berita dan penerima berita atau informasi wajib mengetahui gaya belajar masing-masing. Berdasarkan klasifikasinya dari para ahli sebelumnya gaya belajar dibedakan menjadi tiga pokok hal yaitu audio, visual dan kiestetik. Gaya belajar ada tiga yaitu gaya belajar visual (melihat), gaya belajar auditori (mendengar), dan gaya belajar kinestetik (bergerak dan menyentuh) (De Porter, 2010) hal ini diperkuat dari pendapat (Hartanti \& Arhartanto, 2003) macam-macam gaya belajar berdasarkan preferensi sensori ini dibedakan menjadi tiga gaya belajar yaitu gaya belajar visual, auditorial, dan kinestetik. Berdasarkan teori, gaya belajar setiap manusia sebenarnya dapat diidentifikasi. Karena bersifat individu maka pengamatan dapat dilakukan dengan secara personal dengan melibatkan individu. Salah satu cara yang dapat dilakukan dalam melakukan identifikasi gaya belajar adalah dengan menggunakan pengamatan pada indera. Untuk mengetahui gaya belajar yang disukai siswa seseorang bisa dengan memperhatikan gerakan mata dan mendengarkan pembicaaraan yang disampaikan (Dryden, Gordon , \& J, 2001) (Miller, T. J. E, 1993). Selain dengan pengamatan indera gaya belajar juga dapat dilakukan pengamatan melalui pemanduan. Pemanduan dapat dilakukan dengan mudah jika sebelumnya diri sendiri telah memahami arti dari gaya belajar denga harapan dapat memberikan 
hasil yang maksimal bagi diri orang lain (Nasution, 2008).

Proses pembelajaran yang berjalan dua arah mengharuskan interaksi yang aktif dalam mengedepankan proses pembelajaran. Dari sisi pemberi informasi, jika seamkin bervariasi gaya belajar yang dilibatkan dengan menggunakan media ajar, akan memungkinkan semakin tinggi hasil belajar yang dihasilkan dari peserta didik (Sumarsono \& Anisah, 2018). Seorang pemberi informasi diharapkan dapat secara cakap mengidentifikasi kecenderungan peserta didik tentang gaya belajarnya.

\section{METODE}

Setiap metode yang digunakan dalam setiap penelitian merupakan cara ilmiah untuk mendapatkan hasil yang rasional, empiris dan sistematis. Penelitian ini merupakan penelitian deskriptif kuantitatif, subyek yang dilibatkan dalam penelitian ini meliputi dua kelas yang dikenai Program implementasi Dosen Sekolah (PDS) yaitu pada mata kuliah kepelatihan dasar yang berada di jurusan Pendidikan jasmani kesehatan dan rekreasi, Fakultas Keguruan dan Ilmu pendidikan (FKIP) di Univsersitas Musamus. Instrumen yang digunakan dalam penelitian ini adalah angket skala belajar, wawancara terstruktur dan dokumentasi. Teknik analisis yang digunakan dalam penelitian ini adalah statistik deskriptif dalam bentuk prosentase. Hasil dari analisis angka selanjutnya ditabulasikan dan diberikan keimpulan pernyataan dari hasil perhitungan analisis data. Interperstasi dari hasil kesimpulan dalam penelitian ini digunakan sebagai penyataan hasil penelitian.

\section{HASIL DAN PEMBAHASAN}

Deskripsi subyek penelitian yag dilibatkan dalam penelitian ini adalah mahasiswa jurusan pendidikan jasmani kesehatan dan rekreasi angkatan tahun 2017 yang memprogram mata kuliah kepelatihan dasar. Adapun jumlah dari mahasiswa keseluruhan berjumlah 64 mahasiswa yang terbagi dari dua kelas. Mata kuliah kepelatihan dasar merupakan mata kuliah prasarat yang wajib diprogram mahasiswa pada semester lima. Implementasi dosen PDS yang sudah dilaksanakan di jurusan PJKR secara hasil penelitian dapat dijabarkan sebagai berikut:

\section{Kecenderungan Gaya Belajar Mahasiswa}

Hasil implementasi PDS yang dilakukan pada mahasiswa jurusan pendidikan jasmani kesehatan dan rekreasi, pada kecenderungan gaya belajar mahasiswa dapat dipaparkan sebagai berikut: 


\section{Gaya Belajar Visual}

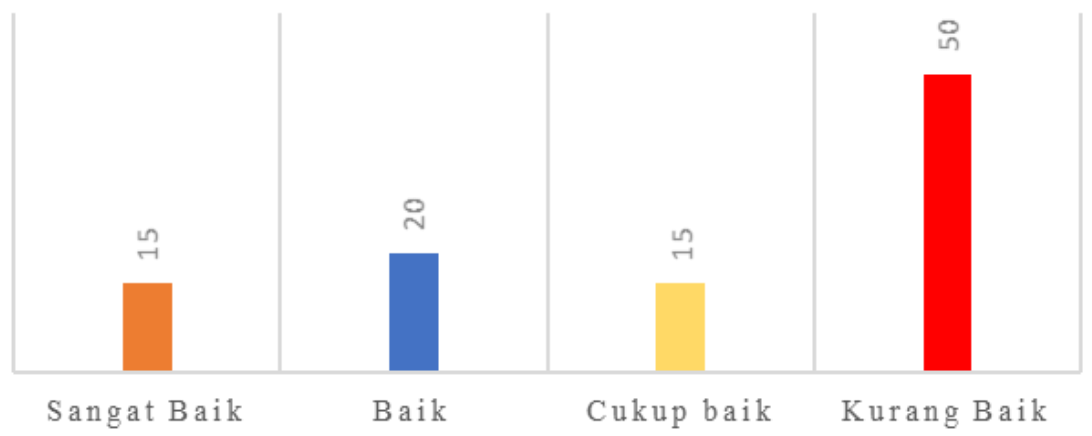

Diagram 1. Tingkat kecenderungan menggunakan gaya belajar visual

Berdasarkan keterangan diagram diatas dapat diketahui bahwa kecenderungan mahasiswa pada impelmentasi program dosen di Sekolah (PDS), pada pernyataan gaya belajar visual cenderung masih belum baik. Hal ini dikarenakan pada materi implemntasi, materi kuliah yang diajarkan secara teori hanya dijelaskan melalui keterangan gambar dan video. Hal ini menimbulkan rasa penasaran hanya sebentar saja, akan tetapi selanjutnya mahasiswa hanya sekedar menonton saja.

Hasil implementasi PDS yang diterapkan di mahasiswa yang mengikuti mata kuliah kepelatihan dasar selanjutnya diberikan tanggapan dari sudut pandang gaya belajar audiotori. Adapun hasil tanggapan dari gaya belajar audiotori dapat dijelaskan melalui gambar diagram berikut ini:

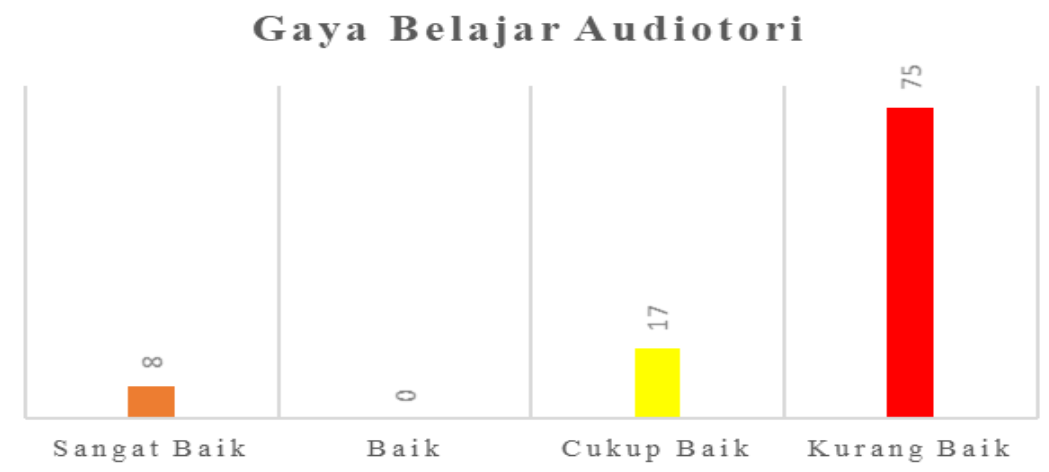

Diagram 2. Tingkat kecenderungan menggunakan gaya belajar audiotori

Berdasarkan keterangan diagram diatas dapat diketahui bahwa kecenderungan mahasiswa pada impelmentasi program dosen di Sekolah (PDS), pada pernyataan gaya belajar audiotori cenderung masih sangat kurang. Hal ini dikarenakan pada materi implemntasi, imlu yang diberikan dari dosen penjelasan menggunakan media power point yang berisi suara mendapat respon mahasiswa yang sangat membosankan. Audio media yang sangat kecil, meyebabkan mahasiswa hanya 
melihat penjalasan dari gambar dan video kepalaatihan saja.

Adapun tanggapan mahasasiswa dengan menggunakan gaya belajar selanjutnya adalah menggunakan gaya belajar kinestetik.
Penjabaran dari gaya belajar kinestetik mahasiswa dalam mengikuti implementasi PDS pada mata kuliah kepelatihan dasar dapat dijelaskan sebagai berikut:

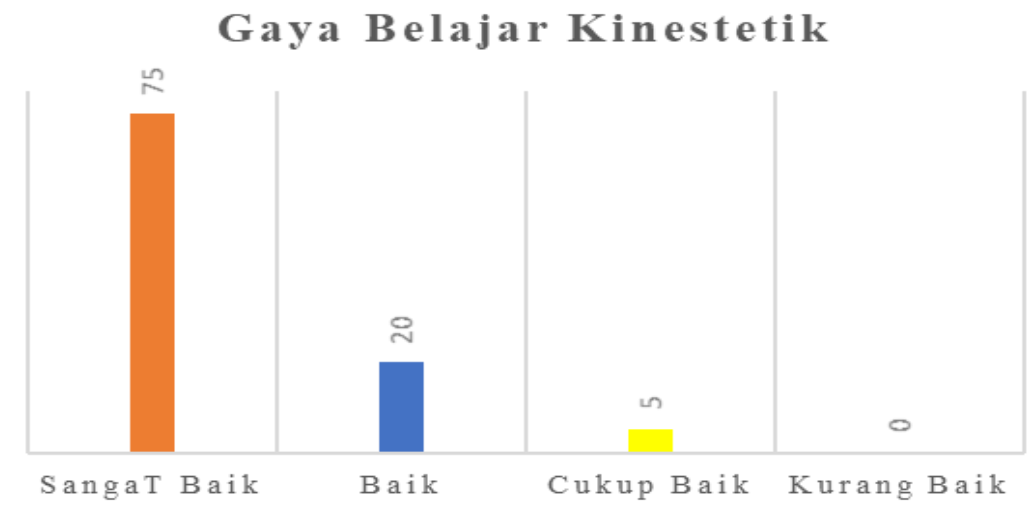

Diagram 2. Tingkat kecenderungan menggunakan gaya belajar kinestetik

Berdasarkan keterangan diagram diatas dapat diketahui bahwa kecenderungan mahasiswa pada impelmentasi program dosen di Sekolah (PDS), pada pernyataan gaya belajar kinestetik cenderung sangat baik dibandingkan dari gaya belajar sebelumnya. dari konfirmasi kepada mahasiswa yang telah mengikuti mata kuliah kepelatihan dasar, mahasiswa lebih menyenangi materi yang diberikan melalui gerak langsung atau praktek. Penjelasan dosen dengan diikuti praktek dalam memahami jenis gerak tertentu dapat di ketahui dan difahami secara pasti.

\section{Kendala yang dihadapi mahasiswa dalam mengikuti perkuliahan}

Implementasi PDS yang dilakukan di perkuliahan pada dasarnya adalah sambungan rangkaian kegiatan dari kegiatan PDS sebelumnya. Dosen yang sudah melakukan implemntasi dari pengalaman yang sudah dilalui di program sebelumnya. adapun jenis dari kendala impelemtasi dapat dijelaskan beberapa hal yaitu, pertama mahasiswa sangat menginginkan pembelajaran mata kuliah yang dilaskanakan tepat waktu perkuliahan, materi yang diebrikan sesuai dengan arahan kurikulum yang sudah dijelaskan di awal perkuliahan. Kendala mahasiswa dalam mengikuti perkuliahan adalah media interaktif yang digunakan dalam perkuliahan yang sangat minimalis. Kedua adalah kendala pemberian informasi yang digunakan melalui jenis video gerak menyebaban mahasiswa hanya menhabiskan waktu dalam menyimak, padahal pemberian video dapat diatur seusi waktu perkuliahan atau hanya pengantar diawal dan penutup 
diakhir saja. Ketiga, tugas yang diberikan oleh mahasiswa dalam bentuk daring melalui aplikasi edmodo, hanya membuang-buang waktu saja. Hal ini dikarenakan pembelajaran yang dilaksanakan menggunakan media internet sedangkan pada implementasinya masih banyak mahasiswa yang belum mengerti dan menggunakan internet.

\section{Solusi yang dibuat guna mengatasi permasalahan}

Berdasarkan permasalahan dari yang sudah dijabarkan diatas, hasil penelitian dari kegiatan implementasi PDS pada mata kuliah Kepalatihan Dasar ini, dianjurkan solusi adalah implementasi program PDS yang sudah dilaksanakan harus mengacu pada kurikuum jurusan supaya jika seleai program perkuliahan dapat berlangsung kembali tanpa ada materi kuliah yang belum tersampaikan. Media daring yang sudah digunakan dalam menstimulasi efektifnya perkuliahan dapat di cairkan dengan sosialaisasi terlebih dahulu kepada mahasiswa, minimal sudah menguasai internet dan mengusasi komputer. Motivasi yang harus disampaikan dari dosen kepada mahasiswa wajib dilangsungkan terus menerus supaya dapat berjalan perkuliahan yang sangat solutif. Perkulaiahn pada jurusan pendidikan jasmai keseharatan dan rekreasi seharusnya selalu dikaitkan degan materi praktek supaya tidak terkesan hanya kuliah hafalan tanpa ada respon gerak. Pendekatan dengan menerapkan suasana belajar aktif dapat diterapkan kepada mahasiswa suapaya saling mamhami pemahaman ilmu sesuai dengan yang diajarkan oleh dosen. Untuk mekasimalkan ketercapaian materi yang disampiakan dapat ditempuh dengan melengkapi alat peraga sesuai dengan materi yang sesuai.

\section{SIMPULAN}

Gaya belajar mahasiswa mempunyai ciri khas yang sangat bervariasi. Khususnya pada mahhasiswa jurusan pendidikan jasmani yang dilakukan program impleemantasi PDS membuktikan bahwa mahhasiwa lebih cenderung menggunakan gaya belajar kinestetik. Hal ini dapat dijelaskan bahwa bembelajaran yang sesuai dengan materi kuliah praktek selalu mewajibkan untuk dijelaskan dengan contoh utamanya contoh gerak. Ada tiga jenis siswa yang berkecenderungan bergaya kinestetik, visual dan auditori. Siswa yang memiliki kecenderungan Kinestetik adalah siswa yang mudah menerima informasi dengan gerakan tubuh sehingga sangat suka dengan gerakan tubuh sehingga sangat menyukai praktik. Siswa yang memiliki kecenderungan visual menyukai simbol dan gambar, rapi dan teratur, serta menyukai warna. Sedangkan siswa yang memiliki kecenderungan Auditori lebih suka untuk mendengarkan penjelasan, serita petualangan, gagasan dan kisah-kisah populer (Asmani, 2012). Sesuai dengan masukan sebagai solusi pembeajaran yang sudah dilakukan dapat disertakan materi yang seuai dengan arahan kurikulum. Pendekatan 
yang yang sesuai dengan agaya belahjar setiap peserta didik dapat dijadikan pijkan dalam menentukan pendekatan dan media pembelajaran yang efektif.

\section{DAFTAR PUSTAKA}

Asmani, J. M. (2012). Tips menjadi guru inspiratif, kreatif, dan Inovatif. Yogyakarta: DIVA Press.

De Porter, B. (2010). Quantum Learner (alih bahasa). Bandung: Kaifa.

Dryden, Gordon , \& J, V. (2001). Revolusi Cara Belajar (The Learning Revolution ) Belajar akan efektif kalau anda belajar dalam keadaan Fun. Jakarta: KAIFA.

Hartanti, \& Arhartanto. (2003). Profil Gaya Belajar Mahasiswa Baru. Indonesian Psycgological Journal Vol. 18, No. 3, 307.

J. Philip, C.B. Rao, T. Jayakumar, B. Raj. (2000). A New Optical Technique for Detection of Defects in Ferromagnetic Materials and
Components. NDT\&E International, (hal. 289-295).

Miller, T. J. E. (1993). Brushless Permanent - Magnet and Reluctance Motor Drives . (T. M. Hammon P, Penyunt.) New York, USA: Oxford University Press Inc.

Nasution. (2008). Berbagai pendekatan dalam proses belajar mengajar Cetakan ke 11. Jakarta: Bumi Aksara.

Sumarsono, A., \& Anisah, A. (2018). Media Audio Visual sebagai Solusi Efektif Pembelajaran Teknik Gerak. Jurnal Pendidikan Jasmani dan Olahraga, 5.

Susilo, J. M. (2006). Gaya Belajar Menjadikan Makin Pintar. Yogyakarta: Pinus.

Uno, H. (2004). Landasan Pembelajaran. Gorontalo: Nurul Janah.

Winkel. (2005). Psikologi Pengajaran, Edisi Revisi. Jakarta: Raja Grasindo Persada. 